\title{
LIVER TRANSPLANTATION FOR ACUTE LIVER FAILURE - a 5 years experience
}

\author{
Cyntia Ferreira Gomes VIANA, Tarciso Daniel Santos ROCHA, Fernanda Paula CAVALCANTE, \\ José Telmo VALENÇA Jr., Gustavo Rêgo COELHO and Jose Huygens Parente GARCIA
}

\begin{abstract}
Background - Fulminant hepatic failure carries a high morbidity and mortality. Liver transplantation has markedly improved the prognosis of patients with fulminant hepatic failure. Aim - To evaluate the outcome of 20 patients with acute liver failure and indication for liver transplantation. Methods - A retrospective review of 20 patients with acute liver failure and indication for liver transplantation was performed. Patients were divided into two groups: group A with 12 patients who underwent liver transplantation and group B with 8 patients who did not receive liver transplantation. Both groups were analyzed according to age, sex, ABO blood type, etiology of acute liver failure, time on list until transplantation or death, and survival rates. Group A patients were additionally analyzed according to preoperative INR, AST, and ALT peak values and MELD (Model for End-stage Liver Disease) scores; intraoperative red blood cells and plasma transfusion and cold ischemia time; postoperative lenght of intensive care unit and hospital stay, and needed for dialysis. Results - Group A: there were four men and eight women with an average age of 24.6 years. The average liver waiting time period was 3.4 days and MELD score 36 . Seven patients are alive with good hepatic function at a medium follow-up of 26.2 months. The actuarial survival rate was $65.2 \%$ at 1 year. Group B: There were two men and six women with an average age of 30.9 years. The mean waiting time on list until death was 7.4 days. All patients died while waiting for a liver donor. Conclusion - Despite the improvements in intensive care management, most patients with acute liver failure and indication for liver transplantation ca not survive long without transplant. Liver transplantation is potentially the only curative modality and has markedly improved the prognosis of those patients.
\end{abstract}

HEADINGS - Liver transplantation. Liver failure, acute.

\section{INTRODUCTION}

Acute liver failure (ALF) is defined by the presence of hepatic encephalopathy occurring as the consequence of severe liver damage in patients without previous clinically liver disease ${ }^{(1)}$. The most prominent causes include drug-induced liver injury, viral hepatitis, and autoimmune liver disease; many cases $(\sim 20 \%)$ have no discernible cause ${ }^{(5)}$.

Fulminant hepatic failure, with a clinical picture that may include cerebral edema, hemodynamic instability, renal failure, and metabolic disturbances, carries a high morbidity and mortality. Most series suggested less than $15 \%$ of survival rate without liver transplantation, despite improvements in intensive care management ${ }^{(5)}$. Liver transplantation (LTx) has markedly improved the prognosis of patients with $\mathrm{ALF}^{(2)}$.

The aim of this article was to evaluate the outcome of 20 patients with acute ALF and indication for LTx according to the Kings College Criteria.

\section{METHODS}

A retrospective review of 20 patients with ALF and indication for LTx according to the Kings College Criteria was performed, between May 2002 and April 2007. The study was approved by the Ethics Committee of our institution. Patients were divided into two groups: group A with 12 patients who underwent LTx and group B with 8 patients who did not receive LTx, because there was not any liver donor within available time.

Both groups were analyzed according to age, sex, ABO blood type, etiology of ALF, time on list until transplantation or death, and survival rates. Group A patients were additionally analyzed according to preoperative INR, AST, and ALT peak levels and MELD (Model for End-stage Liver Disease) scores; intraoperative red blood cells (RBC) and plasma transfusion and cold isquemia time; length of postoperative intensive care unit (ICU) and hospital stay, and needed for dialysis.

Centro de Transplante de Fígado do Ceará, Fortaleza, CE, Brazil

Correspondence: Dr. Fernanda Paula Cavalcante - Rua Cap. Francisco Pedro, 1290 - Rodolfo Teófilo - 60430-370 - Fortaleza, CE. Brazil.

E-mail: cavalcantefp@yahoo.com.br 
All transplanted patients received a whole-sized cadaveric allograft from an ABO-compatible liver donor. Immunussupression was based on tacrolimus and prednisone regimen in all transplanted patients. Actuarial survival rates were calculated by the KaplanMeier technique.

\section{RESULTS}

Group A: there were four men and eight women with an average age of 24.6 (11-52) years. Four patients had ABO blood type $\mathrm{A}$ and eight, type $\mathrm{O}$. The mean waiting time on list was $3.4(0-12)$ days. ALF's etiology included three $(25 \%)$ patients with Wilson's disease, two (16.6\%) with autoimmune hepatitis, one $(8.3 \%)$ with drug-induced liver disease, one $(8.3 \%)$ with hepatitis virus A, and five others (41\%) had no identified cause. Preoperative and intraoperative data are describe in Table 1. Mean ICU and floor unit stay was 11.2 (3-37) and 25.7 (12-54) days, respectively. During the post transplant management, three patients needed dialysis. Seven patients are alive with good hepatic function at a medium follow up of 26.2 (3-55) months. One patient died during the LTx procedure from multiorgan failure, three patients died from sepsis in the ICU a few days after transplant, and another one also died from sepsis, but after 16 months of transplant. Actuarial survival rates were $65.2 \%$ at 1 year. Survival rates were higher in group A when compared to those in group $\mathrm{B}(P<0.05)$.

TABLE 1. Group A preoperative and intraoperative variables

\begin{tabular}{lc}
\hline Preoperative & Values \\
\hline INR & $4.9(2.3-10)$ \\
AST peak (u/L) & $395.8(80-1029)$ \\
ALT peak (u/L) & $336.9(23-724)$ \\
MELD Score & $35.9(29-49)$ \\
\hline Intraoperative & Values \\
\hline Cold isquemia time (minutes) & $387.4(240-625)$ \\
RBC transfusion (units) & $3(0-7)$ \\
Plasma tranfusion (units) & $6(2-10)$ \\
\hline
\end{tabular}

Data are presented as mean and standard deviations

$\mathrm{RBC}=$ red blood cells; INR = International Normalized Ratio

Group B: there were two men and six women with an average age of 30.9 (13-50) years. The mean waiting time on list until death was 7.4 (1-23) days. When compared to patients in group A, they were older (mean age of 30.9 years against 24.6) and waited longer on list (7.4 days against 3.4 days), however those differences were not statistically significant $(P>0.05)$. Three patients had ABO blood type B and five, type O. Just one (12.5\%) patient with hepatitis virus A had the etiology of ALF identified. No artificial hepatic support was used. None of them received LTx because there was not any liver donor within available time and they all died on list.

\section{DISCUSSION}

ALF was originally described as occurring within 8 weeks of the onset of the symptoms in a previously healthy person.
Patients with ALF have a poor prognosis without LTx and the surgical therapy has changed the outcome of this serious clinical condition. The role of medical therapy is to prevent clinical complications such as infections and cerebral edema, the most common causes of death ${ }^{(1)}$.

Patient survival rate with LTx ranges between $60 \%$ to $76 \%$ in the literature ${ }^{(4)}$. We found similar results in our series, where we achieved an actuarial survival rate of $65.2 \%$ at 1 year.

Sepsis was the most common cause of death among the transplanted patients, three $(75 \%)$ out of four patients died from that condition a few days after transplant and they were the only transplanted patients who needed dialysis in the postoperative management.

One patient died from multi-organ failure during the LTx procedure. She was a 23 years-old female with drug-induced ALF, had the highest MELD score in our series (49), waited for 2 days on list, needed dialysis and mechanical ventilation before transplantation, and developed hemodynamic instability right before surgery. This fact shows the need for a more careful selection of patients eligible for transplantation.

There is not any evident consensus in the literature when the patient, waiting for a LTx, accurately looses the indication for LTx due to the emergence of multi system organ failure ${ }^{(6)}$. We believe in the clinical judgment as key factor conducting this problem, leaving out patients with acute respiratory distress syndrome (ARDS), unmanageable hemodynamic instability, resistant metabolic derangements, and other untreatable clinical conditions where the liver transplant surgery probably will be not effective.

Even being considered the top priority in the LTx waiting list in our region and allowing ABO-compatible liver donors for ALF, eight patients in our series with ALF could not find a compatible donor and they all died on list. Three of them had type B blood, a more scarce blood type in our population. Even considering that it is difficult to compare two not homogenous groups in a prospective analysis, there was not any statistically significant difference between groups A and B according to age and time on list, indicating that LTx might be the only variable contributing to the differences in the survival rates between both groups. These results suggest that patients with ALF do not have much time to wait for a liver donor and that LTx might be the only chance they have to survive, however a prospective controlled randomized study is necessary to confirm the results.

The rapid development of ALF associated with a worldwide shortage of organ donors limits the applicability of LTx in this setting. Alternatives to overcome this problem, using living related donors for LTx, have been offered as a therapeutic option with good initial results in adults and children ${ }^{(3)}$. Although experience is still limited, the use of hepatocyte transplantation and bioartificial extracorporeal system may supply in the future the increasing demand for organs ${ }^{(7)}$.

\section{CONCLUSION}

Despite the improvements in intensive care management, most patients with ALF and indication for LTx, can not survive 
long without transplant. LTx is potentially the only curative modality and has markedly improved the prognosis of those patients. There might be effective political measures to increase the total number of organ donors. Alternatives to overcome the shortage of organs, as to make ALF a top priority on list not only in our region, but in our country, might help to reduce the total number of patients with ALF who die year after year on the waiting list. Finally, with adequate training, hospital resources, and a multidisciplinary team, we can achieve as good results in LTx for ALF as for any other indication.

Viana CFG, Rocha TDS, Cavalcante FP, Valença Jr T, Coelho GR, Garcia JHP. Transplante hepático na hepatite fulminante - uma experiência de 5 anos. Arq Gastroenterol. 2008;45(3):192-4 .

RESUMO - Racional - Objetivo - Avaliar a evolução de 20 pacientes com insuficiência hepática aguda e indicação de transplante hepático. Métodos - Foi realizado estudo retrospectivo de 20 pacientes com insuficiência hepática aguda e indicação de transplante hepático. Os pacientes foram divididos em dois grupos: grupo A com 12 pacientes que foram submetidos a transplante hepático e grupo B com oito pacientes não submetidos a transplante hepático. Ambos os grupos foram analisados de acordo com idade, sexo, tipagem sangüínea, etiologia da insuficiência hepática aguda, tempo em lista até o transplante ou até o óbito e sobrevida. Os pacientes do grupo A foram ainda analisados de acordo com o escore MELD (Model for End-stage Liver Disease), valores de pico pré-operatório de INR, AST e ALT, necessidade de transfusão de concentrado de hemácias e plasma fresco congelado durante o transplante, tempo de isquemia fria, tempo de permanência hospitalar e em unidade de terapia intensiva e necessidade de diálise no pós-transplante imediato. Resultados - Grupo A: o tempo médio de espera em lista até o transplante foi de 3,4 dias e o MELD médio, de 36. Sete pacientes continuam vivos com boa função hepática em um tempo médio de seguimento de 26,2 meses. A sobrevida atuarial em 1 ano foi de $65,2 \%$. Grupo B: foram estudados dois homens e seis mulheres com média de idade de 30,9 anos. O tempo médio de espera em lista até o óbito foi de 7,4 dias. Todos os pacientes foram a óbito esperando por um doador. Conclusão Mesmo com todos os avanços nos cuidados de terapia intensiva, a maioria dos pacientes com insuficiência hepática aguda e indicação de transplante hepático não sobrevivem por muito tempo sem o transplante. O transplante hepático é potencialmente a única terapêutica curativa atualmente disponível e melhorou consideravelmente o prognóstico desses pacientes.

DESCRITORES - Transplante de fígado. Falência hepática aguda.

\section{REFERENCES}

1. Busuttil RW, Klintmalm GB. Transplantation of the liver. 2nd ed. Philadelphia: Elsevier-Saunders; 2005

2. Iwatsuki S, Stieber AC, Marsh JW, Tzakis AG, Todo S, Koneru B, Makowka L, Gordon RD, Starzl TE. Liver transplantation for fulminant hepatic failure. Transplant Proc. 1989;21(1 Pt 2):2431-4.

3. Liu CL, Fan ST, Lo CM, Tam PK, Saing H, Wei WI, Yong BH, Tsoi NS, Wong J. Live donor liver transplantation for fulminant hepatic failure in children. Liver Transpl. 2003;9:1185-90.

4. Montalti R, Nardo B, Beltempo P, Bertelli R, Puviani L, Cavallari A. Liver transplantation in fulminant hepatic failure: experience with 40 adult patients over a 17 -year period. Transplant Proc. 2005;37:1085-7.
5. Ostapowicz G, Fontana RJ, Schiodt FV, Larson A, Davern TJ, Han SH, McCashland TM, Shakil AO, Hay JE, Hynan L, Crippin JS, Blei AT, Samuel G, Reisch J, Lee WM. US Acute liver failure study group. Results of a prospective study of acute liver failure at 17 tertiary care centers in the United States. Ann Intern Med. 2002;137:947-54.

6. Sass DA, Shakil AO. Fulminant hepatic failure. Liver Transpl. 2005;11:594-605.

7. Watanabe FD, Mullon CJ, Hewitt WR, Arkadopoulos N, Kahaku E, Eguchi S, Khalili T, Arnaout W, Shackleton CR, Rozga J, Solomon B, Demetriou AA. Clinical experience with a bioartificial liver in the treatment of severe liver failure. A phase I clinical trial. Ann Surg. 1997;225:484-91. 